\title{
Optimization of Profit-Sharing Financing at Islamic Banking in Indonesia
}

\author{
Selamet Riyadi ${ }^{*}$, Muhammad Iqbal², Annisa Arifah Pangastuty ${ }^{3}$, \\ Arianto Muditomo ${ }^{4}$ \\ 1234Department of Management, Faculty of Economics and Business Perbanas Institute \\ *Corresponding Author: selamet.riyadi@perbanas.id
}

\begin{abstract}
The purpose of this study is to identify factors that can encourage an increase in profitsharing financing. These factors are third-party funds in the form of mudharabah deposits, non-performing financing, equivalent rate, operational efficiency ratio, economic growth, and inflation. The research method uses a co-integration and error correction model (ECM) with a sample of the Islamic banking industry in Indonesia from the first quarter of 2015 to the third quarter of 2020. The results show that the factors that encourage profit-sharing financing are the growth of third-party funds in the form of mudharabah deposits, nonperforming low funding, low equivalent rate, operational efficiency, and economic growth. These factors are the key to driving the growth of profit-sharing financing. This research contributes to providing various alternative strategies in encouraging the growth of profitsharing financing, such as increasing retained earnings from profit, providing attractive profit-sharing incentives, transparency of financial reports to attract people to invest in Islamic banks, prevention and supervision of non-performing financing, be careful in determining the ratio by taking into account several internal and external aspects, as well as paying attention to the movements of existing economic growth.
\end{abstract}

Keywords: economic growth; equivalent rate; mudharabah deposits; non-performing financing; profit-sharing financing

\section{INTRODUCTION}

Islamic banks, as part of the national banking system, have an important role in the Indonesian economy (Riyanto, 2016). Islamic banks are banks that run operations based on sharia principles. Islamic banks are not much different from conventional banks. The fundamental difference between the two lies in the principles of financial or operational transactions. One of the principles of Islamic banking is the principle of profit sharing. In contrast to conventional banking, which implements an interesting system, Islamic banking emphasizes the profit-sharing system.

In practice, Islamic banks distribute funds to the public in the form of financing. Financing is funding carried out by financial institutions, an Islamic bank, to its customers. According to Amelia \& Hardini (2017), financing has an important role in boosting the 
economy of small people by creating jobs that ultimately reduce unemployment (Syarief et al., 2020). Good financing growth helps the community to improve their welfare (Dyatama \& Yuliadi, 2015).

Based on the purpose of its use, Islamic financing is divided into four categories, namely: financing with the principle of buying and selling (such as murabaha), leasing (such as ijarah), profit and loss sharing (such as mudharabah and musyarakah), and financing with a complementary contract (Karim, 2016: 97). Of the four principles, buying and selling, leasing, and profit-sharing are most often implemented in the banking world. Financing with the principle of profit-sharing is a characteristic of Islamic banks and a differentiator from conventional banks. Financing products with profit-sharing principles include mudharabah and musyarakah. Mudharabah is a contract of cooperation between two parties, where the first party provides all capital and the other party becomes the manager (Kasmir, 2016: 249). In comparison, musyarakah is a contract of cooperation between two or more parties to conduct certain businesses (Kasmir, 2016: 248).

Financing with the principle of profit-sharing is expected to be able to dominate other types of available funding in Islamic banks because the profit-sharing system is expected to drive productive businesses so that it is possible to create new jobs. The high proportion of profit-sharing type financing is also believed to reduce economic inequality, which will have an impact on increasing economic opportunities for people who have high potential to contribute to capital accumulation and the creation of added value (Giannini, 2013; Abdul-Rahman \& Nor, 2016; Syarief et al., 2020). Profit-sharing financing has also been proven to be able to boost the economic growth of a country (Chowdhury et al., 2018) and contribute to industrial growth in driving productive businesses (Bougatef et al., 2020).

Mudharabah financing requires a high level of mutual trust between the fund owner and fund manager (Giannini, 2013). Therefore, seriousness is needed in managing mudharabah financing, because according to (Abdul-Rahman \& Nor, 2016) there are some obstacles that are often encountered in managing profit-sharing financing, including high investment risks (Febianto, 2012), difficulties in choosing the right partner, requests from customers who have low creditworthiness, and lack of capital security. This requires Islamic banks to apply the principle of high-risk high return far better than conventional banks. On the other hand, the rapid growth of financing at Islamic banks in Indonesia is still dominated by murabaha financing (buying and selling), which are considered to not reflect the characteristics of Islamic banks themselves (Pramono, 2013). Similar to Malaysia, non profit-sharing financing is more than profit-sharing financing which uses mudharabah and musyarakah contracts which have many limitations compared to debt-based financing (non profit-sharing) (Mohd Nor \& Ismail, 2020).

In Islamic banking in Indonesia, financing with the principle of buying and selling is far more dominant than profit sharing-based financing, as shown in Figure 1. This is a separate contradiction in the banking industry in Indonesia, which should prioritize the principle of profit-sharing in the distribution of financing compared to the principle of buying and selling. The low distribution of funding with the principle of profit-sharing is certainly a concern. Why did that happen? Certainly triggered by several factors both from the internal and external sides of Islamic banks. 


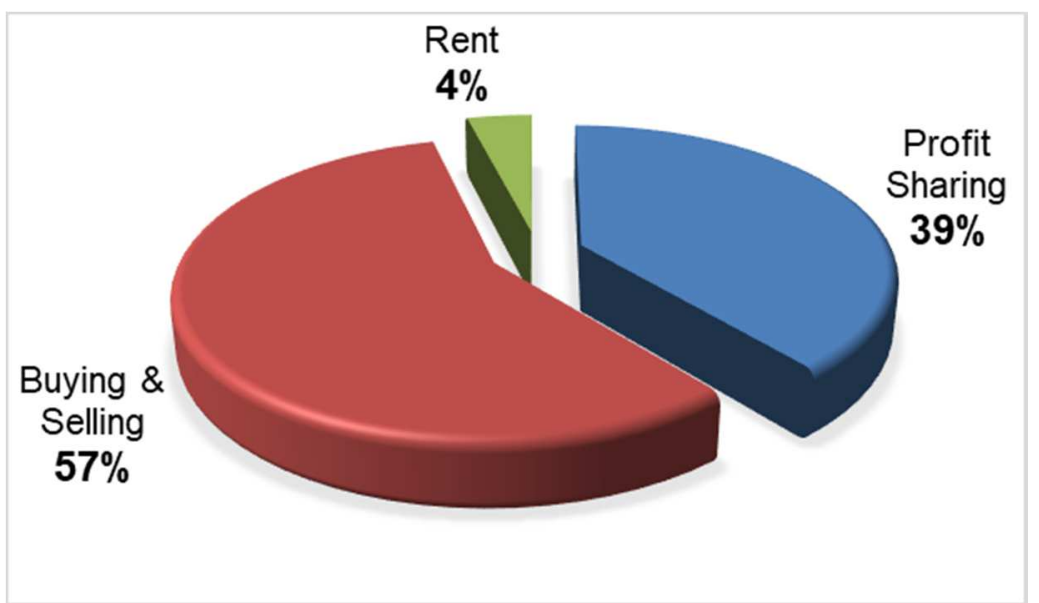

Figure 1. Percentage of Islamic banking financing types in Indonesia in 2019 Source: Financial Services Authority (OJK)

Many factors can influence banks in channeling their financing, both internal and external factors. There are several ways to identify factors that can affect profit-sharing financing as has been done by previous researchers, including the influence of mudharabah deposits (Kiswanto, 2013; Pramono, 2013; Riyanto, 2016), the influence of non-performing financing (Arnan \& Kurniawasih, 2014; Kurniawanti \& Zulfikar, 2014; Annisa \& Yaya, 2015; Destiana, 2016; Jamilah, 2016; Kalkarina et al., 2016; Riyanto, 2016; Murni et al., 2018; Ispad, 2019; Nastiti \& Kasri, 2019), equivalent rate (Kiswanto, 2013; Pramono, 2013; Kurniawanti \& Zulfikar, 2014; Riyanto, 2016), efficiency (Jamilah, 2016; Nastiti \& Kasri, 2019), economic growth (Ayyubi et al., 2017; Anwar et al., 2020; Hafizh et al., 2020) and inflation (Priyanto et al., 2016; Nastiti \& Kasri, 2019; Mubarok et al., 2020).

Several previous studies found different results regarding the factors that affect the size of profit-sharing financing in Islamic banks, as shown by Annisa \& Yaya (2015), Riyanto (2016), and Ispad (2019), which found that Non-Performing Financing (NPF) has a negative effect on profit-sharing financing, while Destiana (2016), Jamilah (2016) and Nastiti \& Kasri (2019) found that NPF has a positive effect on funding profit-sharing. On the other hand Giannini (2013), Arnan \& Kurniawasih (2014), Kurniawanti \& Zulfikar (2014), Kalkarina et al. (2016) and Murni et al. (2018) revealed that NPF has no effect on profit-sharing financing. In addition, there are differences in the results of research conducted by Giannini (2013), Kiswanto (2013), Kurniawanti \& Zulfikar (2014), and Annisa \& Yaya (2015), which found that equivalent rate (profit-sharing rates) has an effect on profit-sharing financing, while Pramono (2013) and Riyanto (2016) found that the profitsharing rate has no impact on funding profit-sharing.

The fact that profit-sharing financing is not more dominant than other types of financing shows that Islamic banks in Indonesia have not yet fully implemented the Islamic financial system. The belief that profit-sharing financing is much fairer \& more beneficial has been proven based on previous studies. Therefore it is important to always look for alternative solutions in encouraging the domination of profit-sharing financing. Identification of the factors that influence profit-sharing-based financing is one way. Knowing what factors influence and do not stimulate the growth of profit-sharing financing is useful in formulating strategies and policies. One form is a growth model for profit-sharing financing, which can reference the Islamic banking industry in controlling growth and slowing down profit-sharing financing. 


\section{HYPOTHESES DEVELOPMENT}

Mudharabah deposits are deposits whose withdrawals can only be made at a certain time in accordance with the customer's agreement with the depositor with the mudharabah agreement. Mudharabah deposits for banks function as a large enough source of funds that can be used to finance bank activities, for the customer to seek a profit or a high enough profit sharing ratio for mudharabah deposits and for the government to help reduce the rate of inflation by reducing the money supply in society. and as financing for national development. Based on the findings of Sholikhah et al. (2017) and Riyanto (2016) found that the greater the mudharabah deposit rate, the greater the financing funds that the bank will provide to customers, so that a first hypothesis can be proposed.

$\mathrm{H}_{1}$ : Mudharabah deposits have a significant positive effect on profit-sharing financing.

Non-performing financing can be defined as a credit whose payments are stagnant and do not meet the minimum obligations set up to credit that is difficult to pay off or even uncollectible (Ispad, 2019). The amount of non-performing financing reflects the level of cost control and financing policies implemented by the bank (Kalkarina et al., 2016). Nonperforming financing (NPF) is one of the bank risks in channeling financing (Iqbal, 2017). The higher the NPF level, the greater the credit risk borne by the bank, as a result banks will be more selective in lending (Ispad, 2019), which in turn reduces the amount of financing. On this basis the second hypothesis is proposed.

$\mathrm{H}_{2}$ : Non-performing financing has a significant negative effect on profit-sharing financing.

Profit sharing or ratio is an agreement between the owner of the fund (shahibulmaal) and the fund manager (mudharib) made at the beginning of the agreement or contract regarding the amount of each portion of the profit sharing to be received. According to Annisa \& Yaya (2015) the profit sharing ratio is an important factor in determining profit sharing in Islamic banks, because the ratio is an aspect that is mutually agreed upon between the two parties conducting the transaction. The profit sharing rate or better known as equivalent rate is the proportion of profit sharing that will be received by fund owners and fund managers who have made a qabul consent/agreement (Rahmawati, 2017). Equivalent rate is obtained from the comparison of the profit sharing received with the total financing on a profit-sharing basis. Thus, Islamic banks are very careful in determining the ratio or level of profit sharing to profit sharing financing customers so that the risk of problematic financing can be controlled.

In addition, according to Kurniawanti \& Zulfikar (2014), equivalent rate is an important factor because the type of profit-sharing financing, namely mudharabah and musyarakah, is a Natural Uncertainty Contract (NUC) which tends to have a high risk compared to other types of financing because the returns obtained by the bank are not certainly. Annisa \& Yaya (2015), Kurniawanti \& Zulfikar (2014) and Rahmawati (2017) found that the greater the equivalent rate set by Islamic banks, the more likely it will spur Islamic banks to distribute profit-sharing based financing, then a third hypothesis can be proposed.

$\mathrm{H}_{3}$ : Equivalent rate has a significant negative effect on profit-sharing financing.

The operational efficiency of a bank shows the lower operating costs and the higher the income that the bank earns. The low cost of bank operations results in reduced costs that must be borne by financing customers, in other words, the cheaper the cost of 
financing. This will encourage customer interest to apply for financing and of course increase the amount of financing. Profit-sharing financing is a type of financing that is sensitive to the level of profit sharing. The bigger the portion for the results of the customer (the portion of the bank is getting smaller because the costs are also small), the greater the amount of financing for the results. As stated by Jamilah (2016), the lower operational efficiency ratio (the more efficient) a bank indicates, the lower its operating costs, the more financing will be distributed. Likewise, what was stated by Nastiti \& Kasri (2019) that operational efficiency has a negative effect on the amount of financing disbursed. When the operational efficiency decreases, there will be an increase in the distribution of financing. From the explanation, the fourth hypothesis is proposed.

$\mathrm{H}_{4}$ : Eficiency has a significant negative effect on profit sharing financing.

High economic growth in a country indicates that production activity in that country has increased. Economic growth has provided optimism for business development. High business activity indirectly requires additional business capital, one of which can be obtained from profit-sharing financing. This indicates that an increase in a country's economic growth will be followed by an increase in profit-sharing financing in that country. As stated by Ayubi et al. (2017), Hafizh (2020) and Anwar et al. (2020) that economic growth has a positive impact on the growth of profit sharing financing. From the above thinking, the fifth hypothesis of this study is proposed.

$\mathrm{H}_{5}$ : Economic growth has a significant positive effect on profit sharing financing.

Inflation is one of the government's indicators in making monetary policy. The increase in inflation will be responded to by an increase in interest rates, which means increasing the price of financing in the banking sector (including Islamic banks) (Mubarok et al., 2020). The high inflation will eventually cause a decline in the distribution of financing, including profit-sharing financing. The same thing was conveyed by Priyanto et al. (2016) and Nastiti \& Kasri (2019) stated that inflation has a significant negative effect on profit-sharing financing.

$\mathrm{H}_{6}$ : Inflation has a significant negative effect on profit sharing financing.

\section{METHOD, DATA, AND ANALYSIS}

This study identifies the factors that influence the growth of profit-sharing financing in the Islamic banking industry in Indonesia. The sampling technique used in this study refers to the purposive sampling technique, which is to select sample members based on certain considerations and criteria. The sample criteria used include current data which is considered more specific than previous data, and the adequacy of relevant data. The first criterion used in determining the sample is the availability of data based on the focus of the study (profit-sharing financing). Where the research variables included in the component of profit-sharing financing are the amount of profit-sharing financing, the NPF of profitsharing financing and the profit-sharing rate (equivalent rate). The availability of data is based on the first criteria starting from 2015 to 2020 . The second criterion for determining the sample is the frequency of the data used. Some variables have monthly frequencies, while other variables have quarterly frequencies. Based on the frequency, the quarterly data were selected. For these two criteria, the sample used is Islamic banking from the first quarter of 2015 to the third quarter of 2020. The data collection method is obtained from published Islamic banking statistics, and the documentary data collection method is taken 
from the Financial Services Authority (OJK), Bank Indonesia (BI) and Central Bureau of Statistics (BPS). Based on the time of collection, the research data used is time series data.

The variables used in this study are profit-sharing financing (PSF) at Islamic Commercial Banks (BUS) and Sharia Business Units (UUS) in Indonesia as the dependent variable, while mudharabah deposits, NPF, equivalent rate, efficiency, economic growth and inflation are independent variables. Profit-sharing financing (PSF) is financing under a production sharing contract, which includes mudharabah, musyarakah, and others. Mudharabah deposits (MD) are deposits whose withdrawals can only be made at a certain time in accordance with the customer's agreement with the depositor with the mudharabah agreement (Annisa \& Yaya, 2015). In this study, the deposits used are deposits with a mudharabah contract.

Non-performing financing (NPF) is problematic financing made by customers. NPF is categorized as substandard, doubtful, non-performing financing. In this study, the data used is only NPF from profit-sharing based financing only. NPF is obtained by the formula below:

$$
\mathrm{NPF}=\frac{\text { Problematic Financing }}{\text { Total Financing }} \times 100 \%
$$

The equivalent rate (ER) is the proportion of profit sharing that will be received by fund owners and fund managers who have made a qabul consent / agreement (Rahmawati, 2017). In this study, the data used is only the level of profit sharing on profitsharing based financing only. The profit sharing rate can be obtained by the formula below:

$$
\mathrm{ER}=\frac{\text { Profit Sharing Received }}{\text { Total Profit Sharing Financing }} \times 100 \%
$$

The efficiency referred to in this research is the operational efficiency of Islamic banking. Operational efficiency is measured by the ratio between operating costs to operating income (BOPO). This ratio is used to measure the level of efficiency and the ability of a bank to carry out its operational activities. The lower the BOPO means the more efficient the bank is in using existing resources in the company (Riyadi, 2017). The BOPO formula is as follows:

$$
\text { BOPO }=\frac{\text { Operating Cost }}{\text { Operating Income }} \times 100 \%
$$

Economic growth and inflation are a small part of a country's macroeconomic indicators. Economic growth reflects the growth in output per capita in the long run. The economic growth referred to in this study is the development of Indonesia's real Gross Domestic Product (GDP) during the observation period compared to the previous year. Meanwhile, inflation reflects the increase in the prices of goods and services that take place continuously. Inflation is commonly used as a monetary policy tool in maintaining financial stability. The inflation measure used in this study is year to year inflation which is obtained from the percentage change in the Consumer Price Index (CPI) during the observation period compared to the previous year.

The analysis technique used in this research is Co-Integration and Error Correction Model (ECM). The Co-Integration and ECM methods are commonly used for time series data that have the potential for spurious regression. This method has the advantage of 
identifying the long-term and short-term effects of the independent variables on the dependent variable simultaneously. This method also has the ability to analyze the consistency of the model proposed in a study. Specifically, co-integration is used to see whether there is consistency in the effect of the independent variable on the dependent variable in the long run, while the ECM itself is used to identify the short-term behavior. The results of the analysis of both will be obtained which variables can be used as indicators in encouraging the growth of responsive revenue sharing in the short term and consistent in the long term.

The short-term and long-term equation models used in research with time series data use the Engel-Granger (EG) two-step ECM model (Engle \& Granger, 1987). The estimation of the short-term regression model is written in equation (1) as follows:

$$
\begin{aligned}
D\left(L n_{-} P S F_{t}\right)= & \beta_{0}+\beta_{1} D\left(L n_{-} M D_{t}\right)+\beta_{2} D\left(N P F_{t}\right)+\beta_{3} D\left(E R_{t}\right)+\beta_{4} D\left(B O P O_{t}\right)+\beta_{5} D\left(E G_{t}\right) \\
& +\beta_{6} D\left(I N F_{t}\right)+\beta_{7} E C_{t}+e_{t}
\end{aligned}
$$

While the estimation of the long-term regression model is written in equation (2) as follows:

$$
L n_{-} P S F_{t}=\alpha_{0}+\alpha_{1} L n_{-} M D_{t}+\alpha_{2} N P F_{t}+\alpha_{3} E R_{t}+\alpha_{4} B O P O_{t}+\alpha_{5} E G_{t}+\alpha_{6} I N F_{t}+e_{t}
$$

According to Widarjono (2017), there are three steps that must be done in using the Co-Integration and ECM method, namely: (1) stationarity test, (2) co-integration test and (3) estimation of the ECM model. The stationarity test is aimed at seeing the similarity in the stationarity level of all research variables, which in this study uses the unit root test with the Augmented Dickey-Fuller (ADF) and Phillips-Perron (PP) methods. While the cointegration test is intended to determine whether there is a long-term balance relationship between research variables, which in this study uses the Engel-Granger (EG) Cointegration Test method. Finally, the ECM model estimation is used to see the short-term effect of the independent variable on the dependent variable and to identify how fast it takes to get the equilibrium value.

Estimation of equations (1) and (2) in the two-step ECM model EG is estimated using Ordinary Least Squares (OLS) method. According to Gujarati et al. (2017) the model estimated by the least squares method is said to be Best Linear Unbiased Estimate (BLUE) if it fulfills several classical assumptions such as being free from multicollinearity, heteroscedasticity and autocorrelation as well as normally distributed residuals. The multicollinearity test uses the Variance Inflation Factor (VIF), the heteroscedasticity test uses the Breusch-Pagan-Godfrey test, and the autocorrelation test uses the BreuschGodfrey Lagrange Multiplier (LM) test. Meanwhile, the residual data normality test used the Jarque-Bera test.

\section{RESULTS}

Based on the results of the data calculations performed, Table 1 presents descriptive statistics of each research variable. The amount of profit-sharing financing (PSF) in the Islamic banking industry during the observation period (quarter I 2015 to quarter III 2020) has always experienced significant growth, even though its value has always experienced volatility. Figure 1 shows the value of profit-sharing financing which always increases from period to period with an average growth of $4.81 \%$. The highest growth occurred in the 
fourth quarter of 2016 amounting to $11.66 \%$, while the lowest growth occurred in the first quarter of 2018 at $0.34 \%$. When viewed from the growth trend, in general the trends that are formed follow seasonal variations. There was an increase at the beginning of the year, fluctuated in the middle of the year and decreased at the end of the year. At the end of the observation period (2020), the growth in profit-sharing financing experienced a slowdown in line with the COVID-19 pandemic. In 2020, the highest growth occurred in May 2020 (amounting to $4.39 \%$ ), the rest continues to slow down to $0.58 \%$ in September 2020 (third quarter 2020). This shows the impact of the COVID-19 pandemic which hit the banking sector due to weakening economic growth (EG) in Indonesia. As shown in Table 1. Indonesia's economic growth reached its lowest point of $-5.32 \%$ in the second quarter of 2020. In previous periods, Indonesia's economic growth has never experienced a slowdown like during the pandemic. Even if a pandemic does not occur, Indonesia's average economic growth can be above $5 \%$.

Table 1. Descriptive statistics

\begin{tabular}{lrccr}
\hline Variable & Mean & Std. Dev. & Maximum & Minimum \\
\hline PSF & 119.7943 & 39.35048 & 181.7205 & 65.8578 \\
MD & 184.8117 & 34.59474 & 232.6396 & 129.8895 \\
NPF & 3.7567 & 0.6991 & 5.3095 & 2.8898 \\
ER & 10.3912 & 1.1607 & 12.0923 & 8.5652 \\
BOPO & 91.0275 & 4.6793 & 97.0050 & 83.0443 \\
EG & 4.1235 & 2.7427 & 5.2659 & -5.3229 \\
INF & 3.6461 & 1.4235 & 7.2600 & 1.4200 \\
\hline
\end{tabular}

Apart from the economic growth (EG) indicator, inflation (INF) in Indonesia during the observation period was also relatively normal. This is indicated by the controlled inflation rate at $3.64 \%$ with the highest value being $7.26 \%$ and the lowest being $1.42 \%$. As for the internal indicators of Islamic banking shown by the collection of third party funds from mudharabah deposits (MD), non-performing financing (NPF), equivalent rate (ER) and efficiency (BOPO), it shows relatively good performance although it is still far from ideal. The average NPF of profit-sharing financing was below the specified limit (5\%), the equivalent rate of profit-sharing financing was also above the Bank Indonesia interest rate during the observation period $(6 \%)$ and the efficiency value of Islamic banking as reflected by BOPO was able to reach $83.04 \%$ with an average of $91.03 \%$. Furthermore, Profit-Sharing Financial of Islamic Bank can be seen in Figure 2.

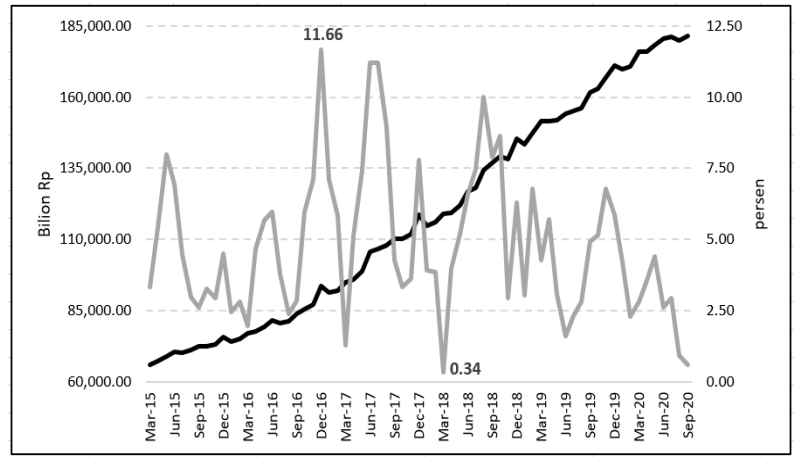

Figure 2. Profit-Sharing Financial of Islamic Bank 2015: Q1-2020: Q3 


\section{Stationarity test}

The results of the stationarity test with the unit root test are presented in Table 2. At the level data, probability t-statistical of the Augmented Dickey-Fuller (ADF) and PhillipsPerron (PP) methods for all variables, the value is not less than 0.05 . This shows that at the level of all data, research variables are not stationary. The test was continued when all data variables were performed with first differencing and the results of prob. $t$-statistical with the ADF and PP methods were almost the same. The probability of $t$-statistic is less than $0.05(\alpha=5 \%)$ even less than $0.01(\alpha=1 \%)$, only one variable on the ADF unit root test is prob. $t$-stat is more than 0.05 , which is economic growth. Even so, the economic growth variable in the unit root test of the PP method, the prob. t-stat is smaller than 0.05 , thus the results can be used as a conclusion from the stationarity test for first differencing data.

Referring to the results above, it can be seen that the data for all research variables have been stationary at the same degree, namely at the first difference level. Thus there is no need to do differencing to a higher level. This means that the ECM model to be estimated later uses the degree of integration at the first level (first difference).

Table 2. Stationer test result with ADF and PP

\begin{tabular}{|c|c|c|c|c|c|c|c|c|}
\hline \multirow{3}{*}{ Variable } & \multicolumn{4}{|c|}{ Level } & \multicolumn{4}{|c|}{ First Difference } \\
\hline & \multicolumn{2}{|c|}{ ADF } & \multicolumn{2}{|c|}{ PP } & \multicolumn{2}{|c|}{ ADF } & \multicolumn{2}{|c|}{$\mathbf{P P}$} \\
\hline & t-Stat & Prob. & t-Stat & Prob. & t-Stat & Prob. & t-Stat & Prob. \\
\hline Ln_PSF & -1.0239 & 0.7249 & -1.1791 & 0.6643 & -6.3131 & 0.0000 & -6.1276 & 0.0001 \\
\hline Ln_MD & -1.1809 & 0.6635 & -1.3562 & 0.5844 & -4.0047 & 0.0062 & -3.9665 & 0.0068 \\
\hline NPF & -2.4371 & 0.1437 & -2.4288 & 0.1458 & -4.4824 & 0.0022 & -4.4934 & 0.0021 \\
\hline ER & -0.2643 & 0.9150 & -0.3044 & 0.9094 & -6.7766 & 0.0000 & -6.7766 & 0.0000 \\
\hline BOPO & -0.2148 & 0.9210 & -0.7232 & 0.8207 & -5.7843 & 0.0002 & -8.9842 & 0.0000 \\
\hline EG & -2.3342 & 0.1712 & -0.3396 & 0.9036 & -1.6787 & 0.4254 & -4.3766 & 0.0028 \\
\hline INF & -1.9151 & 0.3197 & -1.6069 & 0.4625 & -5.9692 & 0.0001 & -5.9692 & 0.0001 \\
\hline
\end{tabular}

Note: $\mathrm{Ln}=$ logarithm natural

\section{Cointegration test}

After obtaining the results of the data stationarity test on the first difference, the next step is to identify whether there is consistency in the long-term relationship of the independent variables (MD, NPF, ER, BOPO, EG \& INF) to the dependent variable for profit-sharing growth (PSF). The results of the cointegration test were obtained from the unit root test of the regression model residuals estimated by the OLS method specified in equation (2). The estimation results of this regression model will later be used to explain the long-term relationship that occurs, after the cointegration test requirements are met. The estimation results of the OLS method are presented in Table 3, while the results of the cointegration test are presented in Table 4.

The results of the cointegration test using the Engel-Granger (EG) cointegration test method with either ADF or PP show that the prob. t-stat value is less than 0.01, which means that the residual (EC) has been stationary at the level data with $\alpha=1 \%$. This shows that there is cointegration between research variables in the long term or in other words there is a long-term balance between variables. The fluctuation of the relationship between the independent variable and the dependent variable in the short term will tend to adjust to achieve its long-term balance. This means that the OLS model estimation results in Table 3 can be used to explain the long-term balance function of the effect of the independent 
variables (MD, NPF, ER, BOPO, EG \& INF) on the dependent variable for the profit-sharing financing (PSF).

The long-term equilibrium model that is formed shows that the prob. t-stat for the Ln_MD, ER and EG variables is smaller than 0.01, which means that in the long term the mudharabah deposits, equivalent rate and economic growth has a significant effect on the profit-sharing financing (Ln_PSF) at $a=1 \%$. The probability value of the BOPO variable $t-$ stat is 0.0226 less than 0.05 , meaning that in the long run, efficiency has a significant effect on the profit-sharing financing at $\alpha=5 \%$. Meanwhile, the prob. $t$-stat variable NPF is 0.0502 less than 0.10, meaning that in the long term non-performing financing only has a significant effect on the profit sharing financing at $\alpha=10 \%$. INF is the only variable whose prob. $t$-stat is greater than 0.1 . This shows that inflation does not have a significant effect in the long run on the profit-sharing financing.

Still based on Table 3, it can be seen that the value of the determination coefficient (RSquared) is very high at 0.9946 , meaning that the formed model is able to explain the effect of the long term variable MD, NPF, ER, BOPO, EG and INF on the PSF variable up to $99.46 \%$ while the rest explained by other variables outside the model. This result is also reinforced by the prob. F-stat which is less than 0.01 indicating that the model formed is suitable to be used to explain the effect of the independent variable on the dependent variable up to $a=$ $1 \%$. Meanwhile, the DW stat value is 1.9495 which is close to the value of 2 indicating that the model is free from autocorrelation. To further ensure that the model is free from autocorrelation, a complete classical assumption test will be carried out in the next section.

Table 3. OLS estimation result

\begin{tabular}{lcccl}
\hline \multicolumn{1}{c}{ Variable } & Coefficient & t-Statistic & Prob. & Information \\
\hline C & 3.70671 & 1.75770 & 0.0979 & \\
Ln_MD & 0.82724 & 5.57130 & 0.0000 & Significant \\
NPF & -0.04170 & -2.11766 & 0.0502 & Significant \\
ER & -0.09696 & -4.90669 & 0.0002 & Significant \\
BOPO & -0.01004 & -2.52412 & 0.0226 & Significant \\
EG & -0.01282 & -4.75671 & 0.0002 & Significant \\
INF & 0.01273 & 1.61763 & 0.1253 & Not Significant \\
\hline R-squared = 0.99461 & & & \\
F-statistic = 492.65540 & & & \\
Prob(F-statistic) =0.00000 & & & \\
Durbin-Watson (DW) stat $=1.94950$ & & & \\
\hline
\end{tabular}

Table 4. Cointegration test result: Unit root test residual (EC)

\begin{tabular}{lcccc}
\hline \multirow{2}{*}{ Variable } & \multicolumn{2}{c}{ ADF } & \multicolumn{2}{c}{ PP } \\
\cline { 2 - 5 } & t-Statistic & Prob. & t-Statistic & Prob. \\
\hline EC OLS & -4.58498 & 0.0016 & -4.58498 & 0.0016 \\
\hline
\end{tabular}

\section{Estimation ECM model}

Based on the results of the stationarity test and cointegration test, the ECM is formed using the residual of the OLS model as the error correction (EC) variable. The estimation results of the ECM model as shown in Table 5 show a large coefficient of determination (Rsquared $=0.68558)$, meaning that the ability of the independent variable to explain its effect on the dependent variable is $68.56 \%$. The F-test result indicated by the F-stat probability of 0.009 indicates that the ECM can be used to explain the short-term effect of the independent 
variable on the dependent variable. The DW stat value is close to the value of 2 , as an early indicator of the freedom of the model from autocorrelation symptoms.

The error correction model used in this study is the Engel-Granger (EG) two-step model. The EG version of the error correction model is said to be valid if coefficient of error correction (EC) is negative and is declared statistically significant (Engle \& Granger, 1987). Based on the ECM estimation results in Table 5, coefficient of error correction (EC) is -0.8734 with a prob t-stat of 0.0098 (less than 0.01), which means that the EC coefficient is negative and significant at $\alpha=1 \%$. These results validate the use of EG's two-step ECM in explaining the short-term and long-term relationships that occur between the variable mudharabah deposits, non-performing financing, equivalent rate, efficiency, economic growth and inflation with profit sharing financing.

Table 5. ECM estimation result

\begin{tabular}{lccll}
\hline \multicolumn{1}{c}{ Variable } & Coefficient & t-Statistic & Prob. & Information \\
\hline $\mathrm{C}$ & 0.025095 & 2.608363 & 0.0206 & \\
$\mathrm{D}\left(\mathrm{Ln} \_\mathrm{r} D\right)$ & 0.411632 & 2.166099 & 0.0481 & Significant \\
$\mathrm{D}(\mathrm{NPF})$ & -0.029231 & -2.107554 & 0.0536 & Significant \\
$\mathrm{D}(\mathrm{ER})$ & -0.043338 & -2.272331 & 0.0394 & Significant \\
$\mathrm{D}(\mathrm{BOPO})$ & -0.001650 & -0.484459 & 0.6356 & Not Significant \\
$\mathrm{D}(\mathrm{EG})$ & -0.008655 & -1.985582 & 0.0670 & Significant \\
$\mathrm{D}(\mathrm{INF})$ & 0.006010 & 1.059878 & 0.3071 & Not Significant \\
EC(-1) & -0.873434 & -2.988244 & 0.0098 & Significant \\
\hline
\end{tabular}

R-squared $=0.68558$

F-statistic $=4.36094$

Prob(F-statistic) $=0.00923$

Durbin-Watson stat $=2.27496$

\section{Classic assumption test}

The OLS and ECM regression models used to explain the long-term and short-term effects of the relationship between macroeconomic indicators and the performance of Islamic banking on the growth of profit sharing financing have been validated. As a final condition that the two models are statistically good models, the final step that must be taken is to ensure that both models meet the classical assumptions of the linear regression model. The classic assumptions that must be fulfilled from the two models are the freedom of the model from multicollinearity, autocorrelation and heteroscedasticity, as well as a normally distributed model residual (normality).

Multicollinearity is a condition of mutual correlation between independent variables. This condition can lead to insignificance of the independent variables which are correlated with each other. In order to see whether there is multicollinearity, Variance Inflation Factor (VIF) is used. The VIF value that is tolerated so that multicollinearity does not occur is 10, more than that it indicates multicollinearity (Hair et al., 2018). The results of the multicollinearity test for OLS and ECM models are presented in Table 6. The VIF value for the OLS model exceeds 10, while for ECM none exceeds 10. In ECM there is no multicollinearity, while the OLS model the Ln_ MD and ER variables have a VIF value of more than 10, although these two variables still have a significant effect on the dependent variable Ln_PSF. This result is an anomaly on the multicollinearity assumption. Even 
though there is multicollinearity, if the two variables have a significant effect, it can be said that the assumption of multi-linearity is fulfilled (Allison, 2012).

Table 6. Multicollinearity test result: Variance Inflation Factors (VIF)

\begin{tabular}{lclc}
\hline \multicolumn{1}{c}{ Variable } & VIF OLS & \multicolumn{1}{c}{ Variable } & VIF ECM \\
\hline Ln_MD & 22.02906 & $\mathrm{D}\left(\mathrm{Ln} \_\mathrm{DM}\right)$ & 1.760518 \\
$\mathrm{NPF}$ & 4.886001 & $\mathrm{D}(\mathrm{NPF})$ & 1.331524 \\
ER & 13.56431 & $\mathrm{D}(\mathrm{ER})$ & 1.824891 \\
$\mathrm{BOPO}$ & 8.923807 & $\mathrm{D}(\mathrm{BOPO})$ & 2.233587 \\
EG & 1.408885 & $\mathrm{D}(\mathrm{EG})$ & 3.364434 \\
$\mathrm{INF}$ & 3.233288 & $\mathrm{D}(\mathrm{INF})$ & 1.458559 \\
& & $\mathrm{EC}(-1)$ & 2.417644 \\
\hline
\end{tabular}

Initial identification of the presence or absence of autocorrelation between the two models (OLS and ECM) has been done previously with the Durbin Watson test and it is suspected that the two models are free from autocorrelation. To further ensure the fulfillment of the model from the autocorrelation assumption, the Breusch-Godfrey Lagrange Multiplier (LM) test was performed. The results of the Breusch-Godfrey LM test for both models can be seen in Table 7, which shows that prob. F-stat and $\chi 2$ are more than 0.05 so that it can be ascertained that the residuals of the two models do not have autocorrelation, so that the assumptions of the model are free from autocorrelation are fulfilled.

The results of the heteroscedasticity test using the Breusch-Pagan-Godfrey test are shown in Table 8. Prob. F-stat and $\chi^{2}$ of both models (OLS and ECM) are more than 0.05, which means that the residuals of both models are homoscedastic (not heteroscedasticity). From these results, it can be concluded that the assumptions of both models are free from heteroscedasticity have been fulfilled.

Table 7. Autororrelation test result: Breusch-Godfrey

\begin{tabular}{lcccc}
\hline Model & F-statistic & Prob. F & Obs*R-squared & $\begin{array}{c}\text { Prob. Chi- } \\
\text { Square }\end{array}$ \\
\hline OLS & 0.07751 & 0.9258 & 0.25190 & 0.8817 \\
ECM & 0.72131 & 0.5060 & 2.36099 & 0.3071 \\
\hline
\end{tabular}

Table 8. Heteroscedasticity test result: Breusch-Pagan-Godfrey

\begin{tabular}{lcccc}
\hline Model & F-statistic & Prob. F & Obs*R-squared & $\begin{array}{c}\text { Prob. Chi- } \\
\text { Square }\end{array}$ \\
\hline OLS & 0.90787 & 0.5137 & 5.84160 & 0.4412 \\
ECM & 1.25017 & 0.3408 & 8.46225 & 0.2936 \\
\hline
\end{tabular}

The normality test for the residuals of the long-term equation model (OLS) and the short-term equation (ECM) is shown in Table 9. The results of the residual data normality test for both models using the Jarque-Bera test are shown by prob. t-stat greater than 0.05 . This means that there is not enough evidence to state that the residual data are not normally distributed, so it can be concluded that the residual data for the OLS and ECM models are equally normally distributed. Thus, the assumption of normality has been fulfilled. 
Table 9. Normality test result: Jarque Bera

\begin{tabular}{lcc}
\hline & t-Statistic & Prob. \\
\hline Residual OLS & 0.64257 & 0.7252 \\
Residual ECM & 0.80281 & 0.6694 \\
\hline
\end{tabular}

\section{Hypothesis testing}

The fulfillment of the classical assumptions of the long-term equation model (OLS) and the short-term equation (ECM) shows that the model formed is already the Best Linear Unbiased Estimate (BLUE), so that the regression coefficient generated by each model (Table 3 and Table 5) can be used to prove the research hypothesis.

Mudharabah deposit (Ln_MD) regression coefficient in the long-term equation (OLS) of 0.82724 has a prob. t-stat is 0.0000 , so it can be said that in the long term mudharabah deposits have a significant positive effect at $\alpha=1 \%$. While in the short term equation (ECM) the regression coefficient is 0.41163 with prob. t-stat 0.0481 , thus in the short term mudharabah deposits have a significant positive effect at $\alpha=5 \%$. The consistency of these two results proves that mudharabah deposits have a significant positive effect on profitsharing financing $\left(\mathrm{H}_{1}\right.$ proven).

The regression coefficient values of non-performing financing (NPF) and equivalent rate (ER) on the long-term and short-term equations are both consistently negative. However, both have different levels of significance. Non-performing financing prob. $t$-stat for the long and short term equation is both significant at $\alpha=10 \%$, while for the equivalent rate in the long term equation it is significant at $\alpha=1 \%$ and for the short term equation it is significant at $\alpha=5 \%$. These results are sufficient to prove that non-performing financing has a significant negative effect on profit-sharing financing $\left(\mathrm{H}_{2}\right.$ proven $)$ and the equivalent rate has a significant negative effect on profit-sharing financing $\left(\mathrm{H}_{3}\right.$ proven).

In the short term efficiency (BOPO) does not have a significant effect on profit-sharing financing, as indicated by the prob. t-stat is very large 0.6356 . However, in the long term, $\mathrm{BOPO}$ has a significant effect on $\alpha=5 \%$ (because the prob. $t$-stat is 0.0226 ). The value of the BOPO coefficient in the short-term and long-term equations is both negative, so it can be concluded that the efficiency measured by the BOPO ratio has a significant negative effect on profit sharing financing $\left(\mathrm{H}_{4}\right.$ proven).

The results of the calculation of the prob. t-stat equations for the long-term and shortterm variables for economic growth (ER) have similarities and differences. In terms of the level of significance, economic growth has a significant effect on different alpha, but the two equations show the same direction of influence (negative). This is contrary to the hypothesis that economic growth has a significant positive effect on profit-sharing financing, thus there is insufficient evidence to accept the research hypothesis $\left(\mathrm{H}_{5}\right.$ not proven).

Of all the research variables, only inflation has no effect on profit-sharing financing, both in the short and long term. This can be seen from the prob. t-stat for the inflation (INF) coefficient greater than 0.1 in each equation. Thus, there is insufficient evidence to state that inflation has a significant negative effect on profit-sharing financing $\left(\mathrm{H}_{6}\right.$ not proven). 


\section{DISCUSSION}

The mudharabah deposit variable was found to have a significant positive effect on profit-sharing financing. The increase in the number of mudharabah deposits as a time deposit product will provide a sense of security for management to take more aggressive financing expansion decisions, so that theoretically when mudharabah deposits increase, the availability of funds to be distributed to the public will be greater and it is expected to have an impact on the growth of profit-sharing financing as well will increase. This finding is corroborated by Kiswanto (2013), Pramono (2013) and Riyanto (2016) who state that the greater the mudharabah deposit rate, the greater the financing funds that the bank will provide to customers.

The increase in the amount of profit-sharing financing that can be distributed to customers as a result of the increase in the amount of mudharabah deposits is quite elastic. In the short term, every $1 \%$ increase in the amount of mudharabah deposits will encourage the growth of profit sharing financing by $0.41 \%$. Meanwhile, in the long term, the growth of mudharabah deposits by $1 \%$ can increase the profit sharing financing to $0.83 \%$. The growth of mudharabah deposits has had a consistent impact on the growth in profit sharing financing. It appears that the long-term impacts that are generated are far greater than the short-term impacts.

The strategy of Islamic banks to continuously encourage the growth of mudharabah deposits must be viewed carefully. Growth that is too aggressive is not impossible to slow down in the future. Slowing growth in mudharabah deposits will also slow down the growth in profit sharing financing. Therefore, the strategy that Islamic banks must implement in encouraging the growth of mudharabah deposits must be carried out consistently. This means that existing growth must be maintained, not to decline if you want to continue to encourage growth in financing for the results.

For the record, the growth of mudharabah deposits is the factor that has the biggest impact compared to other factors after the growth of the profit sharing itself. So the growth in the number of mudharabah deposits in Islamic banks is the dominant factor that becomes the strategy for optimizing profit sharing financing. This is very reasonable, considering the amount of profit-sharing financing channeled mostly comes from mudharabah deposits.

The NPF variable was found to have a significant negative effect on profit-sharing financing. This can be explained that when the NPF rises, management will be more careful in expanding financing and will focus more on activities to maintain the quality of financing and make remedial and recovery efforts. This will indirectly reduce the efforts and focus of banks to expand production profit-sharing financing. With a high NPF, banks will be more careful in providing financing, even if they do not rule out the possibility that banks will reduce their portion of financing. The results of this study are supported by Annisa \& Yaya (2015), Riyanto (2016) and Ispad (2019) which show that NPF has a negative effect on profit-sharing financing.

The impact of a decrease in profit-sharing financing due to an increase in nonperforming financing in the short and long term is not elastic. In the short term, each 1\% increase in the NPF ratio will reduce the financing growth by $0.029 \%$. Meanwhile, in the long term, each increase in the NPF ratio of $1 \%$ will reduce the growth of profit sharing financing by $0.042 \%$. Efforts to maintain the quality of profit-sharing financing are big 
homework for Islamic banks. Currently, the average NPF for the profit-sharing financing category is relatively high, even the minimum NPF in this category is almost $3 \%$. The decline in NPF indicates an increase in the quality of financing and this is what the Islamic banking industry must do, whether it is in order to increase the growth of profit-sharing financing or not.

Equivalent rate was found to have a significant negative effect on profit-sharing financing. This can be explained that basically financing customers will choose a bank that offers a lower equivalent rate relative to other banks that offer a higher equivalent rate, by ignoring other factors that influence the prospective customer's decision making. When equivalent rate rises, the growth in profit-sharing financing has decreased. If the level of equivalent rate does not affect profit sharing financing, the impact is that Islamic banks must consider other aspects, such as improving service quality, product variety, historical relationships, ease of access/proximity to bank locations and others. Therefore, to optimize the profit-sharing financing of a bank, one of them is by reducing the equivalent rate received by the bank, which of course still takes into account several aspects in it. This provides a positive critique of the results of research conducted by Pramono (2013) and Riyanto (2016) which do not find the effect of the level of profit sharing on profit sharing financing. On the other hand, this study strengthens the findings of (Kiswanto, 2013) which states that the higher the equivalent rate, the lower the profit-sharing financing.

Similar to the effect caused by NPF, the effect given by the equivalent rate on profitsharing financing is not elastic enough. In the short term, any decrease in the equivalent rate of $1 \%$ will only be followed by a growth in profit-sharing financing of $0.043 \%$, while in the long term a change in the equivalent rate of $1 \%$ will increase profit-sharing financing by $0.097 \%$. These results indicate that Islamic bank customers are rational customers who are sensitive to the portion of profit sharing. The smaller the portion of profit sharing the customer gets, the less profit-sharing financing is proposed.

$\mathrm{BOPO}$ has a significant negative effect on profit sharing financing. This shows that the more efficient a syarih bank is, the greater the distribution of profit sharing financing. Vice versa, the more inefficient an Islamic bank is, the lower the amount of revenue-sharing financing that is distributed. The results of this study are reinforced by the findings of Jamilah (2016) and Nastiti et al. (2019) which states that BOPO has a negative effect on the amount of financing disbursed.

In the short term, operational efficiency will not have an immediate effect on changes in profit-sharing financing. The operational efficiency carried out by Islamic banks will have an impact in the long term. In the long term, every $1 \%$ decrease in the value of BOPO can increase the growth of profit sharing financing by $0.01 \%$. These results give an indication to Islamic banks to always maintain their level of efficiency. Efficiency that continues to increase and is maintained will encourage the growth of profit-sharing financing. The strategy of optimizing the level of efficiency will not have an impact in the short term, it will only have an impact in the long term. Therefore, what must be done to encourage profit-sharing financing from an efficiency perspective must be done consistently and sustainably, not temporarily.

Based on the research results, high economic growth does not increase the growth of profit-sharing financing and even reduces its growth. In other words, the faster rate of economic growth has actually slowed down the growth rate of financing. Although these results differ from the research of Ayyubi et al. (2017), Anwar et al. (2020) and Hafizh et al. 
(2020), but this is one separate finding. There are several logical reasons that can be expressed from this finding, one of which is the preference of Islamic bank customers towards the types of financing in Islamic banks. As is known, customers of Islamic banks prefer non profit-sharing financing for reasons of convenience and minimal risk. When economic growth increases, the need for working capital will also increase, so it is the type of buying and selling financing that more accommodates this situation. Meanwhile, profitsharing financing experienced a slowdown.

In addition, when viewed from the research observation period (in the long term) economic growth tends to experience a slowdown. As is known in the second and third quarters of 2020, Indonesia experienced a recession with negative economic growth. In difficult times like this, the government has made policy packages to stimulate public productivity, one of which is to encourage the distribution of financing. However, the banking world does not necessarily respond quickly to this, given the high risk of default by customers. However, it is believed that gradually this will tend to improve.

During the current economic slowdown, macroprudential policies in response to the inflation rate are not of particular concern. This is one of the reasons that inflation does not affect profit-sharing financing. At this time, inflation will not have a changing impact on profit-sharing financing. This result is in line with the research of (Hafizh et al., 2020), but not in line with the research of Priyanto et al. (2016) and Nastiti \& Kasri (2019). The level of inflation will not reduce or increase the growth of profit-sharing financing.

\section{CONCLUSION}

Based on the results and discussion previously described regarding the optimization of profit-sharing financing at Islamic banks in Indonesia using cointegation and error correction models, it is concluded that mudharabah deposits have a significant positive effect on profit-sharing financing, which means that the higher the growth of mudharabah deposits, the more also high growth of profit-sharing financing. Meanwhile, nonperforming financing, equivalent rate and efficiency have a significant negative effect on profit-sharing financing. If the non-performing financing and equivalent rate decreased, the growth in profit-sharing financing would increase. Meanwhile, if efficiency of Islamic banks increases, the growth in profit-sharing financing will also increase.

Economic growth as one of the macroeconomic indicators has an inverse effect during the economic slowdown. The slowing pace of economic growth has even spurred the growth of profit-sharing financing. Meanwhile, inflation does not have a significant impact on the growth of profit-sharing financing.

Management of Islamic banks in Indonesia can optimize the proportion of profitsharing financing by utilizing internal and industrial data processing, to make expansion decisions. The mudharabah deposit rate can be used as a reference for short and medium term risk considerations for aggressive, moderate or low expansion decisions considering that the mudharobah deposit rate is a reflection of time deposits whose maturity level can be measured to ensure the availability of funds to finance expansion.

Furthermore, from the results of research related to the negative effect of nonperforming financing on the growth of profit-sharing financing, the non-performing financing indicator can be used as a reference for expansion decisions as well as an early warning indicator for management to not only be expansive in financing but also pay 
attention to monitoring the quality of financing and keep it up make strict remedial and recovery efforts on each given financing asset.

In addition, Islamic banks should be more careful in determining the profit sharing ratio by always considering the calculation of internal funds costs, operational overhead costs and considering the Islamic banking market equivalent rate, conventional banking interest rates and the BI rate reference interest. Finally, from the internal side of the bank, it is a must for Islamic banks to maintain their level of efficiency. Because the level of operational efficiency is consistent which will have a long-term impact on the growth of profit-sharing financing.

Based on the results and discussion, there are several things that can be recommended to the bank. Islamic banks should maintain and improve the components that can affect profit-sharing financing, namely (1) mudharabah deposits by providing attractive incentives for profit sharing rates and transparency in financial reports so that people are interested in investing in Islamic banks, (2) non-performing financing (NPF) through prevention and supervision of problematic financing so that the NPF level of Islamic banks is in a safe position, (3) the equivalent rate is careful in determining the ratio by taking into account several internal and external aspects, (4) consistent and maintained efficiency, not fluctuating by reducing unnecessary costs. Finally, (5) always pay attention to macroeconomic conditions in every policy making.

\section{REFERENCES}

Abdul-Rahman, A., \& Nor, S. M. (2016). Challenges Of Profit-And-Loss Sharing Financing In Malaysian Islamic Banking. Geografia-Malaysian Journal of Society and Space, 12(2), 39-46.

Allison, P. (2012, September 10). When Can You Safely Ignore Multicollinearity? Statistical Horizons. https://statisticalhorizons.com/multicollinearity

Amelia, E., \& Hardini, E. F. (2017). Determinant of Mudharabah Financing: A Study at Indonesian Islamic Rural Banking. Etikonomi, 16(1), 43-52. https:// doi.org/10.15408/etk.v16i1.4638

Annisa, L. N., \& Yaya, R. (2015). Pengaruh Dana Pihak Ketiga, Tingkat Bagi Hasil dan Non Performing Financing terhadap Volume dan Porsi Pembiayaan Berbasis Bagi Hasil pada Perbankan Syariah di Indonesia. Share: Jurnal Ekonomi dan Keuangan Islam, 4(1), 79-104. https:// doi.org/10.22373/share.v4i1.754

Anwar, S. M., Junaidi, J., Salju, S., Wicaksono, R., \& Mispiyanti, M. (2020). Islamic bank contribution to Indonesian economic growth. International Journal of Islamic and Middle Eastern Finance and Management, 13(3), 519-532. https:/ / doi.org/10.1108/ IMEFM-022018-0071

Arnan, S. G., \& Kurniawasih, I. (2014). Pengaruh Jumlah Dana Pihak Ketiga Dan Tingkat Non- Performing Financing Terhadap Pembiayaan Mudharabah Pada Bank Umum Syariah Di Indonesia. Seminar Nasional Ekonomi dan Bisnis, 1-6.

Ayyubi, S. E., Anggraeni, L., \& Mahiswari, A. D. (2017). Pengaruh Bank Syariah terhadap Pertumbuhan Ekonomi di Indonesia. Al-Muzara'ah, 5(2), 88-106. https:// doi.org/10.29244/jam.5.2.88-106 
Bougatef, K., Nakhli, M. S., \& Mnari, O. (2020). The nexus between Islamic banking and industrial production: Empirical evidence from Malaysia. ISRA International Journal of Islamic Finance, 12(1), 103-114. https:/ / doi.org/10.1108/IJIF-05-2018-0052

Chowdhury, M. A. F., Akbar, C. S., \& Shoyeb, M. (2018). Nexus between risk sharing vs non-risk sharing financing and economic growth of Bangladesh: ARDL bound testing and continuous wavelet transform (CWT) approach. Managerial Finance, 44(6), 739758. https:/ / doi.org/10.1108/MF-12-2016-0371

Destiana, R. (2016). Analisis Dana Pihak Ketiga dan Risiko Terhadap Pembiayaan Mudharabah dan Musyarakah Pada Bank Syariah di Indonesia. LOGIKA: Jurnal Ilmiah Lemlit Unswagati Cirebon, 17(2), 42-54.

Dyatama, A. N., \& Yuliadi, I. (2015). DETERMINAN JUMLAH PEMBIAYAAN BANK SYARIAH DI INDONESIA. Jurnal Ekonomi \& Studi Pembangunan, 16(1), 73-83. https:// doi.org/10.18196/jesp.2015.0043.73-83

Engle, R. F., \& Granger, C. W. J. (1987). Co-Integration and Error Correction: Representation, Estimation, and Testing. Econometrica, 55(2), 251-276. https:/ / doi.org/10.2307/1913236

Febianto, I. (2012). Adapting Risk Management for Profit and Loss Sharing Financing of Islamic Banks. Modern Economy, 03(01), 73-80. https:// doi.org/10.4236/me.2012.31011

Giannini, N. G. (2013). Faktor Yang Mempengaruhi Pembiayaan Mudharabah Pada Bank Umum Syariah Di Indonesia. Accounting Analysis Journal, 2(1), 97-103. https:// doi.org/10.15294/aaj.v2i1.1178

Gujarati, D., Porter, D., \& Gunasekar, S. (2017). Basic Econometrics (5th edition). Mcgraw.

Hafizh, M., Hidayah, N., \& Silalahi, P. R. (2020). Macroeconomics And Profit Sharing Financing In Islamic Banking In Indonesia: The Third Parties Fund As Intervening. Jurnal Akuntansi Dan Keuangan Islam, 8(2, Oktober), 131-147. https:// doi.org/10.35836/jakis.v8i2.183

Hair, J. F., Babin, B. J., Anderson, R. E., \& Black, W. C. (2018). Multivariate Data Analysis (8th edition). CENGAGE INDIA.

Iqbal, M. (2017). Perbandingan Pengelolaan Risiko Kredit Perbankan Syariah dan Perbankan Konvensional. Jurnal Keuangan Dan Perbankan, 21(3), 481-497. https:// doi.org/10.26905/jkdp.v21i3.1318

Ispad, A. N. B. (2019). Pengaruh Capital Adequacy Ratio (CAR), Non Performing Financing (NPF), dan Dana Pihak Ketiga (DPK), terhadap Penyaluran Pembiayaan Mudharabah pada Bank Umum Syariah di Indonesia Periode 2015-2017. Prosiding Ilmu Ekonomi, 5, 83-90. http:// karyailmiah.unisba.ac.id/index.php/ekonomi/article/view/15193

Jamilah. (2016). Faktor-faktor yang Mempengaruhi Pembiayaan Mudharabah pada Bank Umum Syariah di Indonesia. Jurnal Ilmu Dan Riset Akuntansi, 5(4), 1-20.

Kalkarina, S., Rahayu, S., \& Nurbaiti, A. (2016). Faktor-faktor Yang Mempengaruhi Pembiayaan Berbasis Bagi Hasil Pada Bank Syariah Di Indonesia (studi Kasus Pada 
Bank Umum Syariah Yang Terdaftar Di Bei). eProceedings of Management, 3(3), 33893395.

Karim, A. A. (2016). Bank Islam: Analisis Fiqih dan Keuangan (kelima). PT RajaGrafindo Persada.

Kasmir. (2016). Dasar-Dasar Perbankan (Revisi 2014). Rajawali Pers.

Kiswanto, W. A. W. (2013). Faktor-Faktor yang Mempengaruhi Pembiayaan Berbasis Bagi Hasil (Profit And Loss Sharing). Jurnal Reviu Akuntansi Dan Keuangan, 3(2), 437-446. https:// doi.org/10.17358/jabm.2.3.281

Kurniawanti, A., \& Zulfikar. (2014). Analisis Faktor-Faktor yang Mempengaruhi Volume Pembiayaan Berbasis Bagi Hasil Pada Bank Umum Syariah di Indonesia. Proceeding Call for Syariah Paper, 145-164. http://publikasiilmiah.ums.ac.id/handle/11617/4718

Mohd Nor, A., \& Ismail, S. (2020). Profit and Loss Sharing (PLS) and Non-PLS Financing in Malaysia: Which One Should Be the One? KnE Social Sciences, 14-25. https:// doi.org/10.18502/kss.v4i6.6585

Mubarok, F., Hamid, A., \& Arif, M. N. R. A. (2020). Macroeconomics fluctuations and its impact on musharaka financing. Jurnal Keuangan Dan Perbankan, 24(2), 164-174. https:/ / doi.org/10.26905/jkdp.v24i2.4061

Murni, Y., Astuti, T., \& Nisa, C. (2018). Determinants of Profit Sharing Financing and Zakat Distribution Based on CAMEL Analysis. Jurnal Keuangan Dan Perbankan, 22(4). https:// doi.org/10.26905/jkdp.v22i4.1994

Nastiti, N. D., \& Kasri, R. A. (2019). The role of banking regulation in the development of Islamic banking financing in Indonesia. International Journal of Islamic and Middle Eastern Finance and Management, 12(5), 643-662. https:// doi.org/10.1108/IMEFM-102018-0365

Pramono, N. H. (2013). Optimalisasi Pembiayaan Berbasis Bagi Hasil Pada Bank Syariah Di Indonesia. Accounting Analysis Journal, 2(2), 154-162. https:// doi.org/10.15294/aaj.v2i2.1437

Priyanto, T., Fahmi, I., \& Ismal, R. (2016). Faktor-Faktor Yang Mempengaruhi Pembiayaan Berbasis Bagi Hasil (Equity Financing) Pada Bank Syariah X. Jurnal Aplikasi Bisnis Dan Manajemen (JABM), 2(3), 281-290. https:/ / doi.org/10.17358/jabm.2.3.281

Rahmawati, F. N. (2017). Analisis Pengaruh Tingkat Suku Bunga, Tingkat Bagi Hasil, Dan Financing To Deposit Ratio (FDR) Terhadap Pembiayaan Mudharabah Studi Pada Bank Umum Syariah Di Indonesia Periode 2014-2016 [Thesis]. Institut Agama Islam Negeri Surakarta.

Riyadi, S. (2017). Manajemen Perbankan Indonesia. Raja Grafindo.

Riyanto, H. (2016). Optimalisasi Pembiayaan Berbasis Bagi Hasil Pada Bank Devisa Syariah Di Indonesia. Jurnal Ekonomi $\mathcal{E}$ Bisnis, 17(1), 54-65. https:// doi.org/10.30659/ekobis.17.1.54-65 
Sholikhah, Z., Pramuka, B. A., \& Adawiyah, W. R. (2017). Determinant of the Equity Based Financing Volume: A Case of Islamic Banks in Indonesia. Research Journal of Finance and Accounting, 8(1), 30-39.

Syarief, M. E., Setiawan, S., \& Khairina, N. N. (2020). Peran Perbankan Syariah dalam Penyerapan Tenaga Kerja pada Sektor Riil. Human Falah: Jurnal Ekonomi dan Bisnis Islam, 7(1), 117-137.

Widarjono, A. (2017). Ekonometrika: Pengantar dan Aplikasinya disertai Panduan EViews (5th ed.). UPP STIM YKPN. 